\title{
The Effectiveness Implementation of Package Payment System (INA-CBGs) at Inpatient Installation of RSUD Zainoel Abidin Banda Aceh
}

\author{
Herianti $^{1}$, Said Usman ${ }^{2}$, Irwan Saputra ${ }^{3}$, Safrizal Rahman $^{4}$, Marthonies $^{5}$ \\ 1,2,3 Magister Program of Public Health, Faculty of Medicine, Universitas Syiah Kuala Banda Aceh, Indonesia. \\ ${ }^{4}$ Sub Devision of Orthopaedics and Traumatology, Faculty of Medicine, Universitas Syiah Kuala/Zainoel Abidin \\ General Hospital, Banda Aceh, Indonesia. \\ ${ }^{5}$ Department of Psychiatry and Mental Health Nursing, Universitas Syiah Kuala, Banda Aceh, Indonesia. \\ dr_herianti@yahoo.co.id,Saidusman@unsyiah.ac.id,iwanbulba@unsyiah.ac.id,rizal.rhmn@gmail.com, \\ Marthonies@unsyiah.co.id
}

\begin{abstract}
Regional General Hospital Dr. Zainoel Abidin (RSUDZA) is one of the public service installations that provide direct health services to the community, especially outpatient and inpatient services. RSUD dr. Zainoel Abidin has implemented a package payment system (INA-CBGs) since January 2014. One of the management elements of implementing this system is planning. Planning (planning) is a process that is very important of all other management functions, which specifically includes the actions to be carried out in order to achieve goals. This study uses a mixed method that uses a combination of descriptive quantitative research and qualitative research with a phenomenological approach through in-depth interviews with informants (in-depth interview). The data used to assess the effectiveness of implementing package payment systems (INA-CBGs) is secondary data taken from hospital medical records. The statistical results assess the frequency distribution by comparing the effectiveness before and after the implementation of the package payment system (INA-CBGs) at RSUD dr. Zainoel Abidin Banda Aceh. The results showed the INA-CBG system was more effective than the Fee for Service (FFS) payment system. The results of this study indicate an increase in efficiency based on service indicators before / after the application of the INA-CBG system, namely (BOR: $75 \%$ / 72\%, AvLOS: 5 days / 4 days, TOI: 2 days / 1 day, BTO: 46 times / 58 times, GDR: 6 per 1000 patients with discharge / 27 per 1000 patients with discharge, and NDR: 8 per 1000/21 per 1000). It can be concluded that the planning process (planning) of the implementation of the package payment system (INA-CBGs) which has been implemented well by the RSUD Dr. Zainoel Abidin Banda Aceh, including the provision of adequate Human Resources (HR), provision of adequate facilities (infrastructure and facilities), the process of formulating and forming strategies and the process of preparing the budget. The implication of implementing this system has been to be able to increase the efficiency of hospital service performance.
\end{abstract}

Keywords

planning, POAC, INACBGs, efficiency

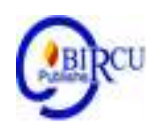




\section{Introduction}

In order to implement the Universal Health Coverage (UHC) by the World Health Organization (WHO) in Geneva in 2014 as a global commitment for all people, the government is responsible for implementing public health insurance through the National Health Insurance (JKN) program. (Thabrany, 2011).

In the current era of globalization, health technology is developing more rapidly along with the emergence of increasingly complex diseases. This requires hospitals to provide good and maximum services. (Wahyuni, 2020)

The above is done to overcome the law of medical money known in America, that is, whatever amount of money provided for health services will run out, both because of the needs of consumers (patients) and because of the wishes of health care providers (health providers) to be able to provide services optimal in accordance with available funds. Similar in Indonesia, health services are consumptive without regard to cost effectiveness and cost efficiency, causing health service costs to be high. (Busse, 2013)

Based on the Minister of Health Regulation No. 76 of 2016 concerning Guidelines for Implementing National Health Insurance (JKN), it was found that there are two hospital payment methods used namely the retrospective payment method and the prospective payment method.

Prospective payment procedures using the INA-CBGs (Casemix) payment system for JKN services were chosen because they can encourage quality fixed services according to standards, control health costs, limit unnecessary or excessive health services and encourage providers to carry out cost containment (cost control). (Casto, 2006)

In Indonesia, since the BPJS Health operation was implemented in 2014 as a National Health Insurance $(\mathrm{JKN})$ provider, payment rates referring to INA-CBGs (Indonesian Case Based Groups) are a payment model to replace claims billed by hospitals. INA-CBGs are payment systems with a "package" system. (Zafar, 2005)

Regional General Hospital Dr. Zainoel Abidin (RSUDZA) is one of the public service installations that provide direct health services to the community, especially outpatient and inpatient services [5]. RSUDZA has become the most advanced referral health facility (FKRTL) that has received BPJS health claims and since the introduction of the INA-CBGs system, in-patient visits have increased.

RSUDZA in order to compete with other hospitals must be able to carry out its functions effectively and efficiently due to the increasing demand for health services. To be able to assess the quality of hospital services, the National Health Service (NHS) introduces 6 (six) requirements in assessing the performance of hospital services, one of which is efficiency. (Giancotti, 2007)

The hospital will be able to operate effectively and efficiently if the management function is carried out properly, starting from planning to supervision.(George, 1997) The successful implementation of package payment systems (INA-CBGs) is effectively proven that hospitals can carry out their functions efficiently in accordance with research conducted in several countries that have implemented the casemix concept. (Duckett, 2007). 


\section{Research Method}

This research is a type of research with a mixed method method that uses a combination of descriptive quantitative research and qualitative research with a phenomenological approach through in-depth interviews with informants (In-depth interview). (Arikunto, 2002) This research will be held at the inpatient installation of the Regional General Hospital, Dr. Zainoel Abidin Banda Aceh.

The sample selection in a quantitative descriptive study was carried out by surveying secondary data, which is a hospital medical record report. The selection of informants was chosen by means of purposive sampling, namely the technique of sampling data sources based on the interests/objectives of the study. Purposive sampling is a sampling technique with certain considerations. (Sugiyono, 2016)

The data collection in this study was conducted with a secondary survey data that is a document review of inpatient medical record reports including length of stay, number of days, and number of patients discharged.

The purpose of the secondary survey data is to compare indicators of hospital service performance efficiency, namely Bed Occupancy Ratio (BOR), Bed Turn Over (BTO), Internal Turn Over (TOI), and Average Length of Stay (AvLOS), Gross Death Rate (GDR) ) and Net Death Rate (NDR) in the period before and after the enactment of package payment rates (INA-CBGs).

\section{Discussion}

\subsection{The Planning Process for Package Payment Systems (INA-CBGs)}

In the POAC management process or function of administration, planning (planning) is the earliest stage before the next three stages of a program / activity. (Fayol, 1949) Similar to the package payment system (INA-CBGs) before the system was implemented in dr. Zainoel Abidin, of course, the hospital has set several plans (planning) to realize the goals and objectives of the organization. As for some of the planning in question is as follows (Gulick, 1965):

\section{a. Provision of Human Resources (HR)}

The informant stated that the HR planning that was carried out was to prepare a number of medical and non-medical personnel in accordance with the labor standards of type A hospitals based on Permenkes No. 56 of 2016 concerning Hospital Classification and Licensing. This statement is also supported by the profile data of RSUD dr. Zainoel Abidin in 2018 about hospital personnel in 2018.

b. Provision of Facilities (Facilities and Infrastructure) by the Hospital

The informant stated that the hospital had provided computers according to needs and other facilities such as UPS, Wi-Fi networks that were connected directly to SIMRS and generators. Based on observations made, the hospital provides a well-functioning computer for each HR person who is directly involved with the application of this system which is equipped with a UPS on each computer unit.

c. Hospital Strategy in Supporting the Implementation of Package Payment Systems (INA-CBGs) at RSUD dr. Zainoel Abidin

The informant stated that the process of formulating or forming a strategy was carried out by assigning tasks to each staff / employee who was directly involved in accordance with their respective duties and work according to standard SOPs. The parties involved in the preparation of the strategy are the director, deputy director, head and head of sub division in each unit, medical committee, doctor or practitioner and BPJS. 


\section{d. Hospital Strategy in}

The informant stated that the budget planning process was carried out by looking at how many shortcomings the facilities had prepared and the activities that would be carried out in the process of implementing the INA-CBGs system, such as training or workshop activities. If it is known how much the lack of funds will be used, then the budget can be calculated.

\subsection{Effectiveness of Implementing Package Payment Systems (INA-CBGs)}

In this study, researchers conducted a quantitative descriptive study to assess the effectiveness of the implementation of package payment systems (INA-CBGs) by conducting a secondary data survey that is a hospital medical record report. The purpose of this survey is to compare indicators of hospital service performance efficiency, namely Bed Occupancy Ratio (BOR), Bed Turn Over (BTO), Internal Turn Over (TOI), and Average Length of Stay (AvLOS), Gross Death Rate (GDR) and Net Death Rate (NDR) in the period before and after the enactment of package payment rates (INA-CBGs).

The following results are statistical comparisons of indicators of hospital service performance efficiency in the period before and after the enactment of package payment system rates (INA-CBGs).

Table 1. Indicators of Hospital Service Performance Efficiency in the Pre-Execution of Package Payment System Tariffs (INA-CBGs)

\begin{tabular}{|l|r|r|r|r|r|r|}
\hline \multirow{3}{*}{ Statistics } & \multicolumn{6}{|c|}{ Indicator } \\
\cline { 2 - 7 } & \multicolumn{6}{|c|}{$\begin{array}{c}\text { Prior to the implementation of the package payment } \\
\text { system (INA - CBGs) in 2006 - 2019 }\end{array}$} \\
\hline & \multicolumn{1}{|c|}{ BOR } & ALOS & \multicolumn{1}{c|}{ TOI } & \multicolumn{1}{c|}{ BTO } & GDR & \multicolumn{1}{c|}{ NDR } \\
\hline Mean & 75,4978 & 5,1744 & 1,6833 & 46,9 & 6,4389 & 8,1467 \\
\hline Median & 76,51 & 5,09 & 1,51 & 51,65 & 6,32 & 4,29 \\
\hline Mode & $65,03^{\mathrm{a}}$ & 5,34 & $1,08^{\mathrm{a}}$ & $12,78^{\mathrm{a}}$ & $5,65^{\mathrm{a}}$ & $3,44^{\mathrm{a}}$ \\
\hline Std. Deviation & 5,1491 & 0,4108 & 0,5167 & 13,2235 & 0,4764 & 11,7559 \\
\hline Minimum & 65,03 & 4,35 & 1,08 & 12,78 & 5,65 & 3,44 \\
\hline Maximum & 83,06 & 5,7 & 2,69 & 56,11 & 7,15 & 39,45 \\
\hline Sum & 679,48 & 46,57 & 15,15 & 422,1 & 57,95 & 73,32 \\
\hline
\end{tabular}

Table 2. Indicators of Hospital Service Efficiency Performance in the Period after the Package Payment System Tariff (INA-CBGs)

\begin{tabular}{|l|r|r|r|r|r|r|}
\hline \multirow{3}{*}{ Statistics } & \multicolumn{7}{|c|}{ Indicator } \\
\cline { 2 - 7 } & \multicolumn{7}{|c|}{$\begin{array}{c}\text { After the implementation of the package payment } \\
\text { system (INA - CBGs) in 2015 - 2019 }\end{array}$} \\
\hline & \multicolumn{1}{|c|}{ BOR } & ALOS & \multicolumn{1}{|c|}{ TOI } & \multicolumn{1}{c|}{ BTO } & \multicolumn{1}{c|}{ GDR } & NDR \\
\hline Mean & 72,854 & 4,822 & 1,4 & 58,194 & 27,262 & 21,356 \\
\hline Median & 72,39 & 4,75 & 1,65 & 60,6 & 6,23 & 5,05 \\
\hline Mode & $69,09^{\mathrm{a}}$ & $4,34^{\mathrm{a}}$ &, $34^{\mathrm{a}}$ & $52,38^{\mathrm{a}}$ & $5,02^{\mathrm{a}}$ & $3,93^{\mathrm{a}}$ \\
\hline Std. Deviation & 3,3246 & 0,4043 & 0,6069 & 4,8356 & 29,5510 & 23,0530 \\
\hline Minimum & 69,09 & 4,34 & 0,34 & 52,38 & 5,02 & 3,93 \\
\hline Maximum & 78,08 & 5,26 & 1,86 & 63,39 & 59,74 & 46,83 \\
\hline Sum & 364,27 & 24,11 & 7 & 290,97 & 136,31 & 106,78 \\
\hline
\end{tabular}

\subsection{Proses Perencanaan Penerapan Sistem Pembayaran Paket (INA-CBGs)}

Planning (planning) is a process that is very important of all other management functions, which specifically includes the actions to be carried out can be achieved objectives 
(Siagian, 2020). RSUD Dr. Zainoel Abidin Banda Aceh City as a type A referral hospital, applies a package payment system (INA-CBGs) as a payment for health services for BPJS patients. To make the system effective, the hospital does some planning. Based on research that has been done, several plans conducted by the hospital, namely is the preparation/provision of human resources, the provision of facilities (facilities and infrastructure), the process of preparing strategies, and budget planning.

Human Resources (HR) is a fundamental thing that needs to be prepared before implementing an activity / program / policy. With the availability of adequate human resources, the activities or programs that will be implemented in an agency can run well. This is consistent with what was stated by Prof. Dato 'Dr. Syed Mohamed Aljunid that if the hospital would benefit from implementing the casemix system, if it provided appropriate training for staff / employees with a series of training modules for health service workers in developing countries.

Based on the results of interviews conducted with informants, information was obtained that in the planning process the implementation of package payment systems (INA-CBGs) at RSUD dr. Zainoel Abidin, the hospital prepared human resources in accordance with the type A hospital staffing standards according to Permenkes No.56 of 2016 concerning Hospital Classification and Licensing. To support the implementation of the package payment system (INA-CBGs) the hospital provided 37 people consisting of 10 ASNs and 27 non-ASNs. In addition to human resources RSUD dr. Zainoel Abidin also provides facilities that can support its implementation.

The hospital also provides electricity generator aids to anticipate sudden power cuts. In addition to anticipating power outages, and hospitals provide UPS devices for each computer unit totaling 37 units. This is in accordance with the opinion of Prof. Dato 'Dr. Syed Mohamed Aljunid that one of the strategies for implementing casemix in hospitals is to use IT systems available in hospitals.

In addition, the hospital also provides a guidebook that can help coders in coding, namely ICD-10 for coding primary and secondary diagnoses and ICD-9 for coding actions / procedures. This is one of the steps in implementing casemix in hospitals, namely the existence of coding that is appropriate for the disease and procedures using ICD-10 and ICD-9 CM [14].

\subsection{Efektivitas Penerapan Sistem Pembayaran Paket (INA-CBGs)}

According to the National Health Services (NHS) to assess the quality of hospital services there are 6 (six) requirements in assessing the performance of hospital services, one of which is efficiency. Efficiency measures can use several indicators namely Bed Occupancy Ratio (BOR), Bed Turn Over (BTO), Internal Turn Over (TOI), and Average Length of Stay (AvLOS) (Huffmann, 1994), Gross Death Rate (GDR) and Net Death Rate (NDR) so that they can assess the effectiveness of the implementation of package payment systems (INA-CBGs) at RSUD dr. Zainoel Abidin Banda Aceh.

From the results of field studies conducted with secondary data survey and hospital medical records, it shows that since the enactment of package payment system (INA-CBGs) rates, hospitals are more efficient (Dwiyanto, 2012). This can be proven by the acquisition of the statistical value of the mean before the implementation of the package payment system (INA-CBGs) in 2006-2019: 75\% BOR, 5 days ALOS, 2 days TOI, 46 times BTO, 6 GDR per 1000 outpatients and 8 NDR per 1000, while the mean after the implementation of the package payment system (INA-CBGs) in 2015-2019: BOR 73\%, ALOS 4 days, TOI 1 day, BTO 58 times, GDR 27 per 1000 patients out and NDR 21 per 1000. 


\section{Conclusion}

The conclusion of this study is the planning process (planning) of the application of the package payment system (INA-CBGs) that has been applied by the RSUD Dr. Zainoel Abidin Banda Aceh, including the provision of sufficient human resources (HR), the provision of adequate facilities (infrastructure and facilities), the process of formulating and forming strategies and the process of preparing the budget.

Suggestions from this research are the hospital to improve the development of human resources in understanding the casemix concept, namely coding, costing and clinical pathway that are well implemented so that the hospital can do cost containment (cost control) and cost efficiency (cost savings), as well as increase the need for facilities (facilities and infrastructure) to support the implementation of package payment systems (INA-CBGs).

\section{References}

Adiwijaya, S., Aritonang, D. V. A. and Mashud, M. 2018. Empowerment Pattern for Thalasemi Patients in Dr. Soetomo Hospital Surabaya. Budapest International Research and Critics Institute-Journal (BIRCI-Journal) (1): 289-298.

Arikunto, S. (2002). Metodologi Penelitian Suatu Pendekatan Proposal. Jakarta : PT. Rineka Cipta.

Busse, R, et al. 2013. Diagnosis related groups in Europe: moving towards transparency, efficiency, and quality in hospitals? BMJ 346, f3197-f3197. https://doi.org/10.1136/bmj.f3197. 2013;

Casto, Layman. 2006. Principles of Healthcare Reimbursement, AHIMA.ISBN 1-58426-070$\mathrm{X}$.

Depkes RI. 2011. Buku Petunjuk Pegisian Pengolahan Data Sistem Informasi Pelaporan Rumah Sakit Lampiran Peraturan Menteri Kesehatan Republik Indonesia NO.1171/MENKES/PER/VI/2011 Tentang Sistem Informasi Rumah Sakit.

Duckett, S. 2007. Casemix Development and Implemetation in Australia. Research Gate

Dwianto, Lestari, T. 2012. Analisis Efisiensi Pelayanan Rawat Inap berdasarkan Grafik Barber Johnson pada Bangsal Kelas III di RSUD Pandan Arang Boyolali Periode Triwulan Tahun 2012. Jurnal Manajemen Informasi Kesehatan Indonesia.

Fayol, H. 1949. General and Industrial Management. Pitman New York.

George, R. T. (1977). Prinsip - Prinsip Manajemen. Jakarta: Bumi Akasara.

Giancotti, M., et al. 2020. Efficiency and Optimal Size of Hospitals: Results of a Systematic Search. PLoS ONE [Internet] 2017 12(3). Av

Gulick, L. 1965. Manajemen is a Science. Academy of Management Journal 1965;8, No. $1: 7-8$.

Huffmann, Edna K. Illinois. (1994) Health Information Management. Psycians Record Company.

Pradata, Y, I., Sarungu, J. J., and Suryantoro, A. 2020. Determinants of Savings and Community Loans in Ngawi District, 2010 - 2018 A Macro Economic Approach. Budapest International Research and Critics Institute-Journal (BIRCI-Journal) (3): 1506-1517Prof. Dato' Dr Syed Mohamed Aljinud. 2013. Sistem Casemix untuk Pemula; Konsep \& Aplikasi untuk Negara Berkembang Penerapan di Indonesia.

Siagian, S. 2014. Manajemen Sumber Daya Manusia [Internet]. Belbuk.com2014]; Available from: https://www.belbuk.com/manajemen-sumber-daya-manusia-p-113.html

Sugiyono. (2016). Metode Penelitian Kuantitatif, Kualitatif dan R\&D. 
Thabrany, H, et al. (2011). Health Insurance in Indonesia: Current Status and the Plan for National Health Insurance. SEARO Regional Overview in South-East Asia (online) http://www.searo.who.int/LinkFiles/Social_Health_Insurance_an3.pdf.

Wahyuni, N. (2020). The Relationship between Social Supports with Nursing Employee Attachment at Dr. R.M. Djoelham Hospital Binjai. Budapest International Research and Critics Institute-Journal (BIRCI-Journal). P. 816-828.

www.rsudza.acehprov.go.id. Profil Rumah Sakit Umum Daerah dr. Zainoel Abidin Banda Aceh. 2018.

available from: https://www.ncbi.nlm.nih.gov/pmc/articles/PMC5371367/

Zafar, A, et al.(2005). Implementing Casemix System in Hospital UKM. Malaysian Journal of Public Health Medicine, 136-140. 